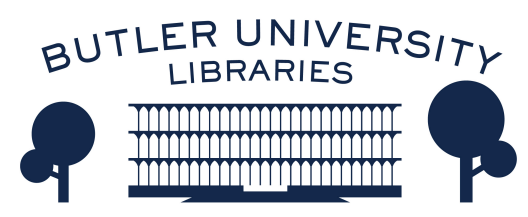

Journal of Hindu-Christian Studies

Volume 22

Article 21

January 2009

\title{
Book Review: "Christianity in India: From Beginnings to the Present"
}

Kristin Bloomer

Follow this and additional works at: https://digitalcommons.butler.edu/jhcs

Part of the Religion Commons

\section{Recommended Citation}

Bloomer, Kristin (2009) "Book Review: "Christianity in India: From Beginnings to the Present"," Journal of Hindu-Christian Studies: Vol. 22, Article 21.

Available at: https://doi.org/10.7825/2164-6279.1448

The Journal of Hindu-Christian Studies is a publication of the Society for Hindu-Christian Studies. The digital version is made available by Digital Commons @ Butler University. For questions about the Journal or the Society, please contact cbauman@butler.edu. For more information about Digital Commons @ Butler University, please contact digitalscholarship@butler.edu. 


\section{Christianity in India: From Beginnings to the Present. Robert Eric Frykenberg, Oxford: Oxford University Press, 2008, 564 pp.}

UNTIL now, no one book in English has attempted to cover the vast topic of Christianity in India. ${ }^{1}$ Robert Frykenberg's recent work does so in a manner that is not only timely and useful for scholars of Indian history and religion; it is also ambitious, to which its heft and length attest. The author, a professor emeritus of history at Northwestern University, has spent the past fifty years of his life studying Christianity in India. As one of a generation of scholars along with Lamin Sanneh, Andrew Walls, Lionel Caplan and others - who arguably pioneered the growing field of "world Christianity," he is an expert to whom we should closely attend.

Frykenberg is sympathetic to missionary activity; he himself was one. But he is sympathetic in an interesting way. The book, he tells us in the Preface, "aims to provide a comprehensive and fresh understanding of the history of Christians, Christian communities, and Christian institutions within the 'Indic' world. It is an attempt to do this by means of an approach which is at once 'Indocentric,' integrative, and contextual - something which has hitherto never been accomplished in a single volume." (vi) Rather than attempt an exhaustive study - impossible for a single volume -Frykenberg succeeds in offering a suggestive, holistic picture representative of various forms of Christianity as they have developed in India.

The work is chronological. Frykenberg's gesture toward Indocentricity leads him to spend the first two chapters, after the introduction, engaged in painting a picture of pre-Christian India. These two chapters are entitled "Contextualizing Complexity I: India's Lands, Peoples, and Social Structures" and "Contextualizing Complexity II: India's Dominant Religious Traditions: SanatanaDharma and Dar-ul-Islam." The chapters assume that the reader knows nothing about the subcontinent. (Indeed, Frykenberg encourages readers who already know something to jump straight to chapter four.) While these early two chapters (of a total of fifteen) may be informative for the beginner, they seem to want to belong to another book. The effect of these early, seventy pages on the narrative frame, however, is strong: Christianity did not enter India in a vacuum, nor did it steamroll in, leveling everything in its path. It entered a specific geography, politics and culture through individual Christians who interacted with other individual Christians and non-Christians from a wide variety of communities. The encounter with people from such a vast number of jatis including those belonging to the Brahman varna (category, lit. "color"), avarnas (those outside the four-fold varna structure), and adivasis (tribal people), and with what later emerged as modern Hinduism and Islam, shaped Christianity, Frykenberg argues, more than Christianity shaped them.

The effect of the missionary encounter, in other words, was not hegemonic. To the contrary, he suggests: the Christian encounter countered hegemony. This counter-hegemonic drive is apparent throughout several examples. In an extensive treatment of Pandita Ramabai Saraswati, for example, Frykenberg highlights the ways in which Ramabai's mission both countered violently misogynistic and hegemonic forms of Hinduism and also avoided various Christian leaders' attempts to control her. The dual identities of Christians in India is another well-developed theme throughout the book.

Unfortunately, Frykenberg works hard in his introduction and conclusion to frame his book theoretically with the term "primal," resulting in some confusion. "Primal religion," he tells us, posits the existence of something universal within all humans:

This presupposition holds that there is no person or people, anywhere in the world or at any time in the past, that has not had to respond, in one way or another, to deeply embedded religious impulses. Whether fully articulated or not, any individual or community that feels anxiety, panic, or threats to survival instinctively resorts to 
primal religion. Primal responses...may be involuntary. (10)

To his credit, he distinguishes "primal" as a positive category, not to be confused with "primitive" or even "animist" - terms that have often been imposed on subjugated peoples considered by colonizers to be uncivilized. All people then, he goes on to say, are primalists even atheists. "As applied to specific religions," he writes, referring to Andrew Walls' 1996 use of the term "primal," "it denotes a basic, elemental impulse within human experience that is anterior, in time, place, and status, to any superimposed religious impulses or subsequent religious institutions" $(10){ }^{2}$ Christianity is distinctively not a primal religion, by these standards. Yet all Christians, by his use of the term, are primalists.

For this reader, such terms hang onto an old precipice, teetering into dangerous territory. It is not entirely clear how the term "primal," when used in conjunction with the term "religion," escapes the derogatory valence of "primitive" a term on which Freud and many early scholars of religion relied heavily. ${ }^{3}$ If primal is a temporal term simply meaning "preintellectualized," "pre-institutionalized," or "prepriestly," why not just say "archaic" or "prior"?

And yet Christianity, Frykenberg repeatedly asserts, is not something alien to India, implanted or imposed by foreigners. It grew within India almost from its own beginning not with western discovery of India, but with indigenous discovery of Christianity. From the emergence of Saint Thomas legends and lore (if not the arrival of the man in the flesh; the jury is still out on that) soon after $54 \mathrm{AD}$ among coastal elite; to Pfarangi Portuguese fleets and the Padroado Real's interactions with Thomas Christians; to Evangelical Christians' dependence on local dubashi agents (cultural translators) who helped them; to Indian Christians' resistance to the "Hindu Raj," Christianity in India both resisted forms of domination and played a role in their development. Certainly, it became its own animal (or, plural, animals) on the Indian subcontinent as nowhere else in the world. How it avoids being primal, however, when growing within India from its own beginnings in relation to indigenous religions, is not clear. The situation seems to elude binaries. Why stick to them?

The Epilogue packs a punch. Christianity seems to be becoming ever-more powerful, if we measure by numbers. Today, given the rise of Pentacostalism, there are ten to fifteen times more Christian missionaries in India than ever before in its history. According to the World Christian Database, the Christian population in 2005 was 68.189 million - the seventh largest in the world, after the USA, Brazil, Mexico, China, Russia, and the Philippines. Though these estimates are controversial, they suggest that the percentage of Christians in India has risen from 2.7 in 1995 to 6.7 in 2005. Frykenberg highlights a tension: while nowhere else have missionary movements begun earlier, lasted longer, or become more highly developed, nowhere too has opposition or resistance to Christianity become more powerful, or subtle; and nowhere are threats to the very survival of Christians more serious.

However true these figures may be, and however real the threats of Hindutva violence, Frykenberg also comes dangerously close to triumphalism, though he explicitly tries to avoid it. Christianity not only reshapes the host culture, he seems to argue, but redeems the host culture as it transcends national and cultural borders. However, he seems to ignore certain "sins" that Christianity may have promulgated. For example, other than a brief mention of the existence of the Goan Inquisition on pages 348 and 360 , he completely leaves out its horrors.

Another picture is possible. To the extent that Christianity itself is a culture, one could argue, indigenous and other forms of Indian religion and culture have transcended borders (or transgressed them) to transform and redeem Christianity.

\footnotetext{
Notes

1 Stephen Neill wrote a two-volume History of Christianity in India, up to 1858; the third volume was never completed. James Hough wrote a fivevolume set published 1839-60 (the last volume edited posthumously by his son), and the Bangalore Church History Association has also published a five-volume set, yet to be completed. But no single volume by a single author on this subject has come into print.
} 
${ }^{2}$ Andrew Walls, "10 Primal Religious Traditions in Today's World," in The Missionary Movement in Christian History: Studies in the Transmission of Faith (Maryknoll, NY: Orbis, 1996), 121 (121-39).
${ }^{3}$ Sigmund Freud, Totem and Taboo.

Kristin Bloomer

University of Hawaii at Manoa

\section{The Perfectability of Human Nature in Eastern and Western Thought. Harold Coward. Albany: SUNY, 2008, 219 pp.}

HAROLD Coward has established himself over the years as one of the world's foremost experts of Hinduism and the Hindu-Christian encounter as well as a respected and learned scholar of other traditions, such as Buddhism, Judaism, and Islam. In this book he draws on all the aforementioned religions, plus philosophy, modern psychology, and yoga, to compare Western (Part I) and Eastern (Part II, with the focus on India) teachings on the possibility of human perfection, perfection understood here as the transcending of a lower ego-centered consciousness and the attainment of a state of perfect freedom, bliss, and pure awareness. What divides Western and Eastern thought on this issue, says Coward, is the general tendency of the former to regard human nature as "finite, flawed, and [of itself] not perfectible" (p. 2), thereby requiring the assistance of divine grace to reach perfection, whereas in Eastern thought there is a greater proclivity to see human nature as 1 . indeed perfectible 2 . occurring already this side of death 3. through effort alone. The author marshals and skillfully evaluates an impressive number of Hindu and Buddhist anthropologies and soteriologies to make his case, with examples taken from both antiquity and modern times.

The three basic questions that Coward puts to the different traditions are these: What exactly is understood by "human nature," what is the ultimate goal of life, and how is that goal achieved? The four chapters in the book's first half take up these themes with regard to western philosophy and psychology, Judaism, Christianity, and Islam. None of them teach that a human being by herself can reach perfection. Although great progress can be made in the development of virtue and self-awareness, there is no final breakthrough, no total annihilation of the ego, according to Western philosophy and psychology, in contrast, for example, to the teaching of Patanjali's Yoga-Sutra.

Judaism and Christianity, even given considerable variations within each of their two communities and histories, tend to agree that sinfulness and human frailty necessitate the mercy and help of God for the attainment of the final goal. Despite Jesus' call to perfection "Be perfect even as your heavenly Father is perfect" (Matt. 5:48) - salvation in Christian understanding is normally regarded as achievable only through the grace of God, Pelagius' position being the main exception. Salvation, understood in orthodox Christianity as freedom in love, is made possible only through God's antecedent unconditional love of the sinner. The perfection of this divinelyinspired human love occurs only after death in total union with God in a transcendent state called the resurrection. And so, though saintliness and holiness are possible prior to death, full perfection is not.

For Islam, as with Judaism and Christianity, the human person is understood as a unity of body, mind, and spirit. Completion of the human is therefore likewise understood as taking place in the resurrection from the dead in the afterlife by a gracious act of a merciful God. But prior to death human perfection and completion are impossible.

In contrast to the above-named Western and Semitic positions the author asserts in chapters 6, 7 and 8 (on, respectively, Indian Philosophy and Yoga Psychology; Hindu Thought; Buddhist Thought) that both Hindu and Buddhist doctrines embrace the view that human perfection, understood as a state of enlightenment and freedom from rebirth, must occur on earth in a human body, so much so that reincarnation back into the world is the necessary presupposition to ensure the 